\title{
STUDY ON ECG CHANGES AND INTERPRETATION IN NORMAL AND ISCHAEMIC HEART DISEASE POPULATION IN A TERTIARY CARE LEVEL HOSPITAL
}

\author{
Jyoti Prasad Deori
}

${ }^{1}$ Assistant Professor, Department of Physiology, Silchar Medical College, Silchar.

ABSTRACT
India is feeling a health transition with expanding burden of ischaemic heart diseases, which have touched epidemic magnitudes
among Indians with atherosclerosis risk factors.

\section{METHODOLOGY}

A one year prospective cohort study conducted regarding Electrocardiogram (ECG) changes over fifty control persons and another fifty persons suffering from IHD in Silchar Medical College, Assam.

\section{RESULTS}

In ECG recording between two groups, there was no significant statistical difference were illustrated in heart rate (RR interval), P-wave duration and voltage, PR interval, QRS complex, QT interval, and mean T-wave duration. In ECG recordings, $20 \%$ IHD cases showed left axis deviation. In control group, ST segments were recorded in isoelectric line while in case group, $58 \%$ and $26 \%$ cases showed ST segments elevation and depression respectively. In IHD case group, $28 \%$ and $72 \%$ cases documented T wave inversion and positive T-wave deflection respectively.

\section{CONCLUSION}

Early cautious ECG interpretation with a proper history taking helps in early intervention and may reduce mortality burden.

\section{KEYWORDS}

ECG, IHD, P Wave, ST Segment, T Wave.

HOW TO CITE THIS ARTICLE: Deori JP. Study on ECG changes and interpretation in normal and ischaemic heart disease population in a tertiary care level hospital. J. Evolution Med. Dent. Sci. 2016;5(59):4105-4107, DOI: 10.14260/jemds/2016/938

\section{INTRODUCTION}

Every cell in the body has electrical property. It shows the difference of electrical nature between outside and inside the cells. The algebraic sum of these electrical responses of cardiac muscles and nodal tissues by electrodes can be documented as the electrocardiogram (ECG). ${ }^{1}$

\section{Ischaemic Heart Disease (IHD)}

The most common cause of death in the western world is ischaemic heart disease and its incidence is increasing day by day. In $90 \%$ of cases, the origin of Ischaemic Heart Disease (IHD) or Coronary Artery Disease (CAD) is due to diminished coronary blood flow secondary to obstructive atherosclerotic vascular lesions. ${ }^{2}$ at present, coronary artery disease due to atherosclerosis is an epidemic in India. It is coming as the major disease accounting for practically one-third of all deaths in India. ${ }^{3}$

Now, ischaemic heart disease has become the most common, serious, chronic, life-threatening illness in the developing and developed world. Cigarette smoking, high fat, and energy rich diet, hypertension, diabetes mellitus, obesity, psychological stress, alcoholism, and sedentary lifestyle are

Financial or Other, Competing Interest: None.

Submission 13-06-2016, Peer Review 10-07-2016,

Acceptance 16-07-2016, Published 25-07-2016.

Corresponding Author:

Dr. Jyoti Prasad Deori,

Assistant Professor,

Department of Physiology,

Silchar Medical College,

Silchar-788014,

Assam.

E-mail:j_deori@rediffmail.com

DOI: $10.14260 /$ jemds/2016/938 associated with emergence of ischaemic heart disease. The people who have genetic predisposition to atherosclerosis may also suffer from this disease. 4,5

\section{MATERIALS AND METHODS}

This prospective cohort study was conducted in the Department of Physiology and Department of Cardiology of Silchar Medical College, Assam from January 2014 to December 2014.

The subjects were randomly selected from the patients and hospital staffs. Out of one hundred number representative persons, 50 cases were taken as a control group and the other 50 numbers diagnosed as cases of Ischaemic Heart Disease (IHD) based on certain inclusion criteria taken as study group.

For each individual, a detailed clinical history was taken and complete physical examination with special reference to cardiovascular examination was conducted. In proforma, history of smoking, alcohol addiction, kidney disorder, liver disorder, diabetes, any familial or genetic disease, prolonged use of any drugs, which may affect the ECG were noted.

In IHD cases, the blood pathology and biochemistry investigation was done whenever required, which includes CBC with ESR, fasting and postprandial sugar, urea, creatinine, lipid profile, electrolytes, TSH, cardiac biomarkers, and routine urine examination. Coronary angiographies were arranged whenever required.

\section{NORMAL SUBJECTS}

\section{Inclusion Criteria}

1. Young individuals $<25$ years of age without any history of major ailment, family history of hypertension, diabetes, dyslipidaemia, etc. 
2. Persons between 25-30 years, treadmill test done, and subjects without any sign of IHD.

3. Persons $>30$ years, coronary angiography done without any sign of IHD or infarction in coronary angiography.

\section{The Subjects taken as Ischaemic Heart Disease}

Diagnosed cases of IHD were taken from Cardiology OPD Ward and CCU of Medical College. They were diagnosed on the basis of history, treadmill ECG test, cardiac enzymes level, coronary angiography, etc.

Data analysed by SPSS version 17.0 with appropriate statistical test i.e. Student's t-test, Microsoft office 2010 excel, and presented in the form of graphs.

\section{RESULTS}

In the control group, forty were male and the rest were female with mean \pm SD of age was $46 \pm 9.5$ years. Among the 50 cases of IHD, 42 cases were men and rest 8 cases were women with mean \pm SD of age was $52 \pm 8.4$ years.

The mean heart rate (RR interval) among the normal (Control) and IHD cases were 81.2 $\pm 12.81 /$ minute and $80.20 \pm 20.39 /$ minute respectively. The relation of mean heart rate between control and case groups were statistically insignificant.

In control group, there was no electrical deviation, but among IHD cases 10 cases showed left axis deviation.

The mean duration of $\mathrm{P}$ wave in control group was $0.0836 \pm 0.011$ seconds in comparison to $0.0864 \pm 0.22$ seconds in case group. The relation of mean $\mathrm{P}$ wave duration was also statistically insignificant between two groups.

The mean voltage of $\mathrm{P}$ wave for control and case group was $0.194 \pm 0.0387 \mathrm{mv}$ and $0.198 \pm 0.0349 \mathrm{mv}$ respectively and their relation was statistically not significant between the two groups.

The statistical relationship of PR interval between control population $(0.1448 \pm 0.0208$ seconds) and case population $(0.1564 \pm 0.027$ seconds) was not statistically insignificant (Paired t test, $\mathrm{p}$ value $>0.05$ )

The mean duration of QRS complex were $0.0804 \pm 0.0154$ seconds and $0.0802 \pm 0.0167$ seconds for control and IHD cases where relation was statistically insignificant.

The ST segment in the control group were within isoelectrical line considering a deflection of $<0.5 \mathrm{mv}$ as isoelectric and among 50 cases of IHD patients 29 cases showed ST elevation, 13 cases presented with ST depression, and rest 8 cases ST segment were within isoelectric line.

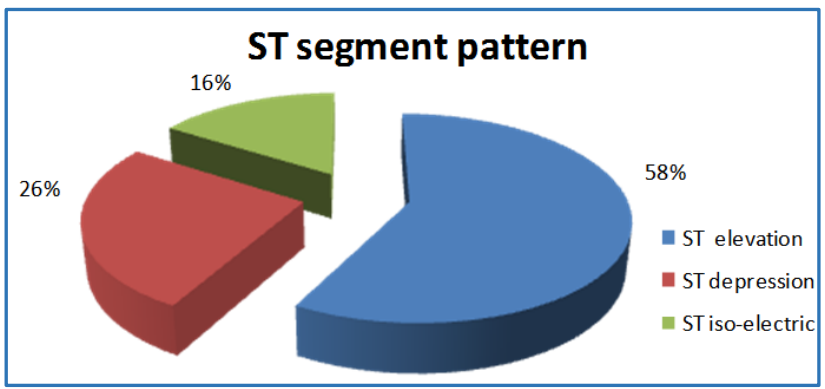

Graph 1: ST Segment Pattern Among 50 IHD Cases

The QT intervals in control group was $0.3592 \pm 0.225$ seconds and for IHD/case group was 0.3624 \pm 0.02959 seconds; the $\mathrm{p}$ value $=0.5418$ was statistically not significant .
The mean $\mathrm{T}$ wave duration were $0.2316 \pm 0.024$ seconds and $0.2404 \pm 0.024$ seconds for control and case groups and $p$ value was not statistically significant.

The $\mathrm{T}$ wave in control group found to be within normal limit and among 50 cases, 14 cases (28\%) showed T wave inversion and 36 cases $(72 \%)$ were with positive deflection of T wave.

\section{T wave pattern among IHD}

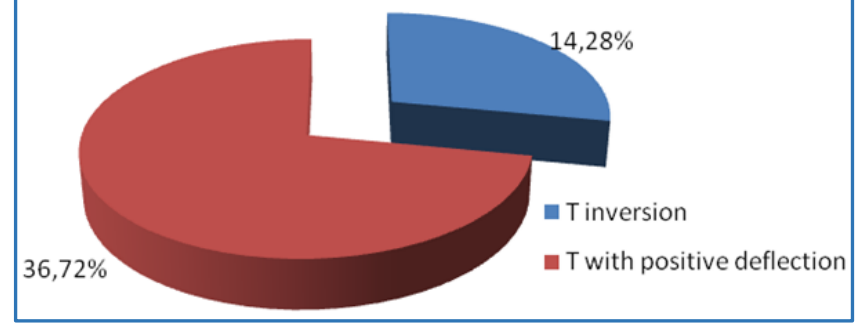

Graph 2: T-Wave Pattern in Case Group

\section{DISCUSSION}

CAD is the principal single cause of death in the United Kingdom and many parts of the world. Early detection with control of modifiable risk factors should be the goal for all preventive programmes specially directing the high-risk groups. ${ }^{6}$

\section{Age}

In the present study, the age range of case group varied from 31-81 years. It correlates considerably with findings of other studies carried by of Julian et $\mathrm{al}^{7}$ Jewitt et $\mathrm{al}^{8}$ and Killip et $\mathrm{al}^{9}$ In the present study, majority of cases belonged to $6^{\text {th }}$ decade of life similar to Rajagopalan et al study. ${ }^{10}$ However, Vakil RJ and Lal et al studies noted the most disease occurrences in the $5^{\text {th }}$ decade of life.7,8,9,10,11,12

\section{Heart Rate}

The mean difference of heart rate between the two groups was statistically nonsignificant, but heart rate was within normal range, $60-100 / \mathrm{min}$. The study conducted by Copie et al showed that heart rate is a powerful predictor of mortality of left ventricular function in acute myocardial infarction after arrival in hospital. This clearly demonstrated that heart rate reflects depressed cardiac activity. ${ }^{13}$

\section{Electrical Axis}

In the present study, among total 100 cases, 10 cases (10\%) displayed left axis deviation with male-female ratio of 3:2. Das et al carried out an ECG assessment over 704 patients age ranged from 20 to 60 years and reported isolated left axis deviation in $2.13 \%$ cases and right axis deviation in $1.85 \%$ of cases. ${ }^{14}$ In a large population-based study De Bacquer et al, mentioned that there were significantly higher occurrence of left ventricular hypertrophy, left axis deviation, arrhythmias in men compared to women. ${ }^{15}$ In Japan, in a cross-sectional study by Shinmura et al over 500 , apparently healthy persons aged 60 years and older did not find any statistically significant relationship between cardiac axis deviation and age changes. ${ }^{16}$

\section{P Wave Changes}

The variation of mean $\mathrm{P}$ wave duration and voltage between two groups was statistically nonsignificant and came within 
normal range of 0.08 to 0.12 seconds and $<0.25$ millivolts respectively. Heikkila et al in their study considered that the $P$ wave value change indicate left heart failure in myocardial infarction. ${ }^{17}$

\section{QRS Complex}

In this study, the mean voltage of QRS complex in normal group was +0.819 millivolts within normal limits. Among the IHD cases, thirty two cases displayed positive deflections and eighteen cases presented with QS pattern. In 1998, Ahto et al conducted an analysis over 488 men and 708 women found that the nature of IHD seems to be less severe among aged women compared to men. Slight ECG variations specifically in the ST and T segments are common with ageing. ${ }^{18}$

\section{ST Segment}

In the present study, in IHD cases, 29 cases recorded ST elevation, 13 cases showed ST depression. Study by Stern et al in diagnostic accuracy of ambulatory ECG monitoring in ischaemic heart disease reported ST deviation and T wave inversion in patients of ischaemic heart disease and severe coronary disease. ${ }^{19}$ To diagnose variant angina, it is crucial to observe transient ST segment elevation on an ECG record during an event of angina pectoris. The ST segment elevation subsides with intake of sublingual nitroglycerine. In a patient with frequent incidents of chest pain, ambulatory ECG recordings is important for diagnosis. ${ }^{20} \mathrm{~A}$ study on ST segment of the ambulatory electrocardiogram in a normal population by Kohli et al showed ST changes of an ischaemic nature happen even in normal population, but they do not essentially represent concealed clinically significant coronary artery disease. ${ }^{21}$ Paradoxically, Gandhi et al in their study mentioned brief episodes of ischaemic ST segment depression among $52 \%$ patients with angina and $9 \%$ control subjects. ${ }^{22}$

\section{CONCLUSION}

Ischaemic heart disease is going to be a major death factor among people with high-risk group. Regular follow up and early interpretation of ECG on the basis of left axis deviation, QRS complex and ST changes altogether help to start early treatment of disease.

\section{REFERENCES}

1. Barrett KE, Barman SM, Boitano S, et al. Origin of the heartbeat and the electrical activity of the heart. In: Barett KE ed. Ganong's Review of Medical Physiology. 24th edn. New York: Mc Graw Hill 2012:521-37.

2. Kumar V, Abbas AK, Aster JC, et al. The heart. Robbins and Cotran pathologic basis of disease. $9^{\text {th }}$ edn. New Delhi: Elsevier 2013:523-78.

3. Garg M, Aggarwal AD, Kataria SP. Coronary atherosclerosis and myocardial infarction. An autopsy study. J Indian Acad Forensic Med 2011;33(1):39-42.

4. Park K. Parks textbook of preventive and social medicine. 23rd edn .Coronary Heart Disease. In: Park K. ed. India: Bhanot 2015:1-9.

5. Gupta MC. Textbook of preventive and social medicine. In: Saha I, Roy RN. eds. $4^{\text {th }}$ edn. Ischaemic heart disease. New Delhi: Jaypee 2013:362-3.
6. Camm AJ, Bunce N. Cardiovascular disease. In: Kumar P, Clark M, eds. Kumar and Clark's Clinical Medicine. $7^{\text {th }}$ edn. Edinburgh: Elsevier 2005:681-810.

7. Julian DG, Valentine PA, Miller GG. Disturbances of rate, rhythm, and conduction in acute myocardial infarction: a prospective study of 100 consecutive unselected patients with the aid of electrocardiographic monitoring. Am J Med 1964;37(6):915-27.

8. Jewitt D. Myocardial infarction. Proc R Soc Med 1967;60(11 Part 1):1086-7.

9. Killip T, Kimball JT. A survey of the coronary care unit: concept and results. Prog Cardiovasc Dis 1968;11(1): 45-52.

10. Rajagopalan RS, Appu KS, Sultan SK, et al. Assessment of supraventricular arrhythmias in acute myocardial infarction. J Assoc Physicians India 1972;20(9):625-34.

11. Vakil RJ. A statistical study of 1281 cases of congestive cardiac failure or myocardial insufficiency in India. Indian Physician 1949;8(10):281-9.

12. Lal HB, Caroli RK. Acute myocardial infarction in higher income group patients. Some clinical, electrocardiographic and biochemical observations. A study of 450 proved cases. Indian Heart J 1967;19(1):12-25.

13. Copie X, Hnatkova K, Staunton A, et al. Predictive power of increased heart rate versus depressed left ventricular ejection fraction and heart rate variability for risk stratification after myocardial infarction. Results of a twoyear follow-up study. J Am Coll Cardiol 1996;27(2):270-6.

14. Das PP, Datta PG, Datta A. Pattern of electrocardiographic changes in preoperative check-up in patients undergoing ENT surgery. BSMMU J 2011;4(2):56-9.

15. De Bacquer D, De Backer G, Kornitzer M. Prevalences of ECG findings in large population-based samples of men and women. Heart 2000;84(6):625-33.

16. Shinmura K, Ebihara Y, Kawamura M, et al. Changes in electrocardiographic findings with aging in a longitudinal study of 500 apparently healthy persons aged 60 years and older. Nihon Ronen Igakkai Zasshi Japanese Journal of Geriatrics 1994;31(5):366-73.

17. Heikkila J, Luomanmaki K. Value of serial $P$ wave changes in indicating left heart failure in myocardial infarction. $\mathrm{Br}$ Heart J 1970;32(4):510-7.

18. Ahto M, Isoaho R, Puolijoki $\mathrm{H}$, et al. Prevalence of coronary heart disease, associated manifestations, and electrocardiographic findings in elderly Finns. Age Ageing 1998;27(6):729-37.

19. Stern S, Tzivoni D, Stern Z. Diagnostic accuracy of ambulatory ECG monitoring in ischaemic heart disease. Circulation 1975;52(6):1045-9.

20. Ardehali R, Schroeder JS. Variant angina. In: Chatterjee K, Anderson M, Heistad D, et al, eds. Cardiology an illustrated textbook. 1st edn. New Delhi: Jaypee Brothers 2013: 940-2.

21. Kohli RS, Cashman PM, Lahiri A, et al. The ST segment of the ambulatory electrocardiogram in a normal population. Br Heart J 1988;60(1):4-16.

22. Gandhi MM, Wood DA, Lampe FC. Characteristics and clinical significance of ambulatory myocardial ischaemia in men and women in the general population presenting with angina pectoris. J Am Coll Cardiol 1994;23(1):74-81. 